- Ricardo Defavery • José Alexandre Rodrigues Lemos - Simone Kashima - José Eduardo Bernardes

Carlos A lberto Scridelli - Dimas Tadeu Covas

- Luiz Gonzaga Tone

\title{
Analysis of the p53 gene by PCR-SSCP in ten cases of Wilms' tumor
}

Department of Pediatrics, Faculdade de M edicina de Riberão Preto, Universidade de São Paulo and Fundação H emocentro de Riberão Preto, Riberão Preto, Brazil

\section{abstract}

CONTEXT: M utations of the $p 53$ tumor suppressor gene are the most frequent alterations observed in human neoplasias affecting adults. In pediatric oncology, however, they have seldom been identified. W ilms' tumor is a renal neoplasia commonly occurring in children and is associated with mutations of the W Tl gene. The correlation between W ilms' tumor and alterations of the $\mathrm{p} 53$ gene has not been well established, with a low frequency of mutations having been reported in this type of tumor. Mutation may be associated with advanced stage disease and unfavorable histology.

OBJECTIVE: To screen for mutations of the $p 53$ gene by the PCRSSCP method and DN A sequencing in cases of W ilms' tumor suggestive of mutation.

DESIGN: Case Report.

CASE REPORT: Evaluations of exons 5-9 of the p53 gene in DN A samples extracted by PCR-SSCP from $10 \mathrm{~W}$ ilms' tumors in children at different stages, and DN A sequencing. Changes in SSCP analysis were observed in exon 8 in two samples. The probable mutations were not confirmed by DN A sequencing. The absence of point mutations in $\mathrm{p} 53$ gene observed in the 10 samples of $W$ ilms' tumor studied agrees with literature data, with DN A sequencing being of fundamental importance for the confirmation of possible mutations.

KEY WORDS: W ilms' tumor. p53 gene. PCR-SSCP. Solid tumors.

\section{INTRODUCTION}

The p53 tumor suppressor gene is located on the short arm of human chromosome 17 (17p13) and it codes for a nuclear phosphoprotein of $53 \mathrm{kDa}$. The function of wild type p53 is the negative regulation of cell proliferation, with a transcription action that inhibits the G1 phase of the cell cycle in the presence of damaged DNA ${ }^{1-3}$ p53 is the most intensely investigated gene in human cancer. ${ }^{2}$ Its mutations have been identified in $50 \%$ of adult neoplasias involving the colon, lung, esophagus, stomach, liver, breast, and uterine cervix. ${ }^{4}$ However, mutations of the p53 gene have been little observed in children. ${ }^{5,6}$

Wilms' tumor is the renal neoplasia most frequently occurring in children, with an incidence of $1: 10,000$ children, especially among those younger than 6 years. ${ }^{7}$ Approximately 5 to $10 \%$ of children with Wilms' tumor have bilateral involvement. Wilms' tumor is associated with congenital abnormalities including genitourinary malformations, sporadic aniridia, mental retardation, and hemihypertrophy. ${ }^{8}$

Mutations of the WT1 gene are associated with Wilms' tumor. ${ }^{9}$ The correlation between p53 gene and Wilms' tumor is not completely understood. There are few reports on mutations of this gene in this tumor type. A possible association with unfavorable prognosis and advanced stage of the disease has been reported. ${ }^{6,9,10}$

In the present study we investigated possible mutation in the regions of the 5-9 exons of the $p 53$ gene in children with Wilms' tumor by the polymerase chain reaction - single strand conformational polymorphism (PCR-SSCP). Samples that presented anomalous migra- 
tion by PCR-SSCP analysis were submitted to automatic DNA sequencing to confirm possible mutations.

\section{CASE REPORT}

Tumor samples from 10 patients with a diagnosis of Wilms' tumor were studied by PCR-SSCP to determine the presence of possible mutations due to genetic changes in the p53 gene. The patients were seen at the Pediatric Oncology Outpatient Clinic of the University Hospital, Faculty of Medicine of Ribeirão Preto, University of São Paulo. The clinical and histological characteristics of the patients ( 7 girls and 3 boys) are presented in Table 1. Mean age at diagnosis was 4.1 years. Histology was favorable in 6 cases and unfavorable in 3 . In one case of bilateral Wilms' tumor the material was insufficient for histopathological analysis. The tumor was stage I in 5 cases, stage III in 1, stage IV in 3, and stage V in 1. The classification of Wilms' tumor was based on the criteria of the National Wilms' Tumor Study.11 Tumor samples were obtained during surgery and DNA was extracted by the phenol/chloroform method. ${ }^{12}$

The possible alterations of the p53 gene in the regions corresponding to exons 5-9 were evaluated by PCRSSCP. Each of the five regions analyzed was amplified by PCR using a pair of corresponding primers ${ }^{13}$ (Table 2). For PCR, each DNA sample $(0.1 \mathrm{mg} / \mathrm{ml})$ was added to a mixture containing $2.5 \mathrm{mM}$ buffer solution $(0.2 \mathrm{M}$ Tris$\mathrm{HCl}, 0.5 \mathrm{M} \mathrm{KCl}, \mathrm{pH}$ 8,4); $10 \mathrm{mM}$ dNTPs (dATP, dCTP, dGTP, dTTP); $1.5 \mathrm{mM} \mathrm{Mg}$ for exons 5, 6, 7 and 8; $2 \mathrm{mM} \mathrm{Mg}$ for exon; a pair of primers $(10 \mathrm{mg} / \mathrm{ml})$ corresponding to the exon under study, and taq polymerase $(5 \mathrm{U} / \mathrm{ml})$, to a final volume of $25 \mathrm{ml}$. All samples were submitted to the following amplification conditions: 35 successive cycles of denaturation (1 minute at $940 \mathrm{C}$ for all exons), annealing ( 1.5 minutes at $61^{\circ} \mathrm{C}$ for exons 5 and $8,54^{\circ} \mathrm{C}$ for exon 6 , 58 ㄷ C for exon 7 and 53으 for exon 9) and extension (1 minute at $72^{\circ} \mathrm{C}$ for all exons).

For SSCP, the PCR products were diluted 1:10 in a solution containing $0.1 \%$ SDS and $10 \mathrm{mM}$ EDTA, and an equal volume of dye with $20 \mathrm{mM}$ EDTA, $95 \%$ formamide, $0.05 \%$ bromophenol blue and $0.05 \%$ xylene cyanol was added. Denaturation was then carried out at $96 \circ \mathrm{C}$ for 10 minutes. A fraction of this solution was put into $6 \%$ nondenaturing polyacrylamide gel and submitted to electrophoresis under the following conditions: $8 \mathrm{~W}, 40 \mathrm{~mA}$ and $200 \mathrm{~V}$ for $2-4$ hours at $4{ }^{\circ} \mathrm{C}$. The gel was stained with silver nitrate, developed, photographed, and analyzed.

For DNA sequencing of the samples with probable mutations screened by PCR-SSCP, a $100 \mathrm{ml}$ al iquot of each PCR product was used for DNA purification. The purified DNA products and the primers labeled with fluorescein ${ }^{13}$ (Table 2) were submitted to the sequencing reaction using the Thermo Sequenase kit (Amersham Pharmacia, Little Chalfont, Buckinghamshire, UK) according to the manufacturer's instructions. Electrophoresis was then carried out using a $7 \%$ non-denaturing gel with an automatic ALF sequencer (Amersham Pharmacia Biotech, Uppsala, Sweden) at $1500 \mathrm{~V}, 25 \mathrm{~mA}$ and $60 \mathrm{~W}$ for 4-6 hours. The DNA sequences obtained for each sample were compared to the normal sequence of the p53 gene obtained from the Gene Bank, sequencing access number x54156.

Table 1 - Clinical and laboratory characteristics of patients with Wilms' tumor submitted to analysis of the p53 gene

\begin{tabular}{|c|c|c|c|c|c|c|}
\hline Case & Age & Sex & Histology/ Staging & Bilateral Metastases & Treatment & Clinical Outcome \\
\hline 1 & 1 & $\mathrm{~F}$ & $\begin{array}{l}* \\
\text { stage V }\end{array}$ & $\begin{array}{l}\text { yes / } \\
\text { no }\end{array}$ & $\begin{array}{l}\text { act/ dox } \\
\text { vin/ rad }\end{array}$ & $\begin{array}{l}\text { DF } \\
\text { (5 years) }\end{array}$ \\
\hline 2 & 3.7 & $\mathrm{~F}$ & $\begin{array}{l}\text { favorable / } \\
\text { stage I }\end{array}$ & $\begin{array}{l}\text { no / } \\
\text { no }\end{array}$ & act/ vin & $\begin{array}{l}\text { DF } \\
\text { (2 years) }\end{array}$ \\
\hline 3 & 1.9 & $\mathrm{~F}$ & $\begin{array}{l}\text { favorable / } \\
\text { stage I }\end{array}$ & $\begin{array}{l}\text { no / } \\
\text { no }\end{array}$ & act/ vin & $\begin{array}{l}\text { DF } \\
\text { (2 years) }\end{array}$ \\
\hline 4 & 5 & M & $\begin{array}{l}\text { favorable / } \\
\text { stage III }\end{array}$ & $\begin{array}{l}\text { no / } \\
\text { abdominal }\end{array}$ & $\begin{array}{l}\text { act/ dox/ vin/ } \\
\text { cisp/ eto/ rad }\end{array}$ & death \\
\hline 5 & 1.8 & M & $\begin{array}{l}\text { favorable / } \\
\text { stage I }\end{array}$ & $\begin{array}{l}\text { no / } \\
\text { no }\end{array}$ & act/ vin & $\begin{array}{l}\text { DF } \\
\text { (4 years) }\end{array}$ \\
\hline 6 & 2 & M & $\begin{array}{l}\text { favorable / } \\
\text { stage I }\end{array}$ & $\begin{array}{l}\text { no / } \\
\text { no }\end{array}$ & act/ vin & $\begin{array}{l}\text { DF } \\
\text { (5 years) }\end{array}$ \\
\hline 7 & 5.2 & $\mathrm{~F}$ & $\begin{array}{l}\text { favorable / } \\
\text { stage IV }\end{array}$ & $\begin{array}{l}\text { no / } \\
\text { pulmonary }\end{array}$ & $\begin{array}{l}\text { act/ vin/ } \\
\text { dox/ rad }\end{array}$ & $\begin{array}{l}\text { DF } \\
\text { (3 years) }\end{array}$ \\
\hline 8 & 5 & $\mathrm{~F}$ & $\begin{array}{l}\text { unfavorable / } \\
\text { stage IV }\end{array}$ & $\begin{array}{l}\text { no / } \\
\text { pulmonary }\end{array}$ & $\begin{array}{l}\text { act/ vin/ dox/ } \\
\mathrm{rad} / \mathrm{cisp} / \\
\text { eto/ ifo }\end{array}$ & death \\
\hline 9 & 12 & $\mathrm{~F}$ & $\begin{array}{l}\text { unfa vorable / } \\
\text { stage IV }\end{array}$ & $\begin{array}{l}\text { no / } \\
\text { liver }\end{array}$ & cisp/ eto/ ifo & $\mathrm{N} \mathrm{I}$ \\
\hline 10 & 4 & $\mathrm{~F}$ & $\begin{array}{l}\text { favorable } \\
\text { stage I }\end{array}$ & $\begin{array}{l}\text { no / } \\
\text { no }\end{array}$ & act/ vin & $\begin{array}{l}\text { DF } \\
\text { (2 years) }\end{array}$ \\
\hline
\end{tabular}

act: actinomycin; dox: doxorubicin; vin: vincristine; cis: cisplatin; eto: etoposide; ifo: ifosfamide; rad: radiotherapy; * preoperative chemotherapy; $N$ I: no information; DF: disease free 
The DNA samples from the 10 Wilms' tumor specimens were submitted to screening by PCR-SSCP for possible mutations of the p53 gene in the regions corresponding to exons 5-9.

Abnormal bands were revealed by SSCP in exon 8 in 2 samples. One was from a patient with bilateral involvement (case 1) (Figure 1) and the other from a patient with favorable histology (case 3). The clinical outcome was good for all of these patients. The DNA sequencing analyses of these 2 samples with altered migration in exon 8 were normal. Thus, point mutation alterations were not confirmed in the sequencing of DNA from the 2 samples.

\section{DISCUSSION}

In the present study we assessed the presence of possible mutations due to genetic alteration in the regions between exons 5 and 9 of the p53 gene in 10 cases of Wilms' tumors affecting children. In 2 cases, altered electrophoretic migration was observed by SSCP but was not confirmed by DNA sequencing.

For the screening of samples with probable mutations of the p53 gene we used PCR-SSCP, a method with approximately $90 \%$ sensitivity and specificity for the detection of mutations confirmed by DNA sequencing in PCR products with 200 base pairs or less. ${ }^{14,15}$ Even though the coding region of the p53 gene consist of 10 exons (the first is non-coding), the analysis of mutations was performed in the region between exons 5 and 9 . The reason for this is that more than $98 \%$ of the mutations of the p53 gene in human neoplasias are located in these exons. ${ }^{5}$ In addition, the region between exons 5 and 8 (codons 126 and 331 with 540 base pairs) contains DNA sequences that code for evolutionarily conserved domains considered to be functionally important. ${ }^{3}$

The false-positive results obtained here by SSCP in 2 cases agree with reports by other investigators who have studied the p53 gene in Wilms' tumor, such as Waber et al. ${ }^{16}$ and Malkin et al., ${ }^{9}$ demonstrating that DNA sequencing is of fundamental importance in the determination of the existence of mutations in a given DNA segment.

According to several reports, the incidence of point mutations of the 553 gene in Wilms' tumors is small.

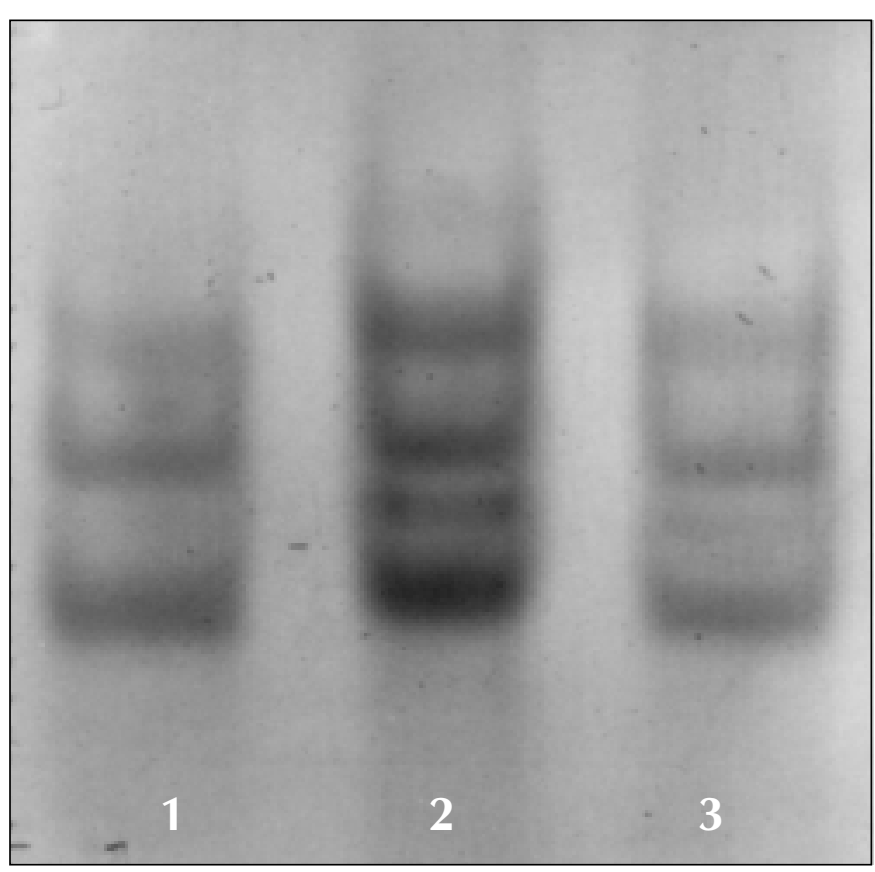

Figure 1 - SSCP on exon 8. Numbers 1 and 3: Normal controls. Number 2: anomalous run (case 1).

Table 2 - Primers, characteristics and amplified regions of gene p53 used in the present study

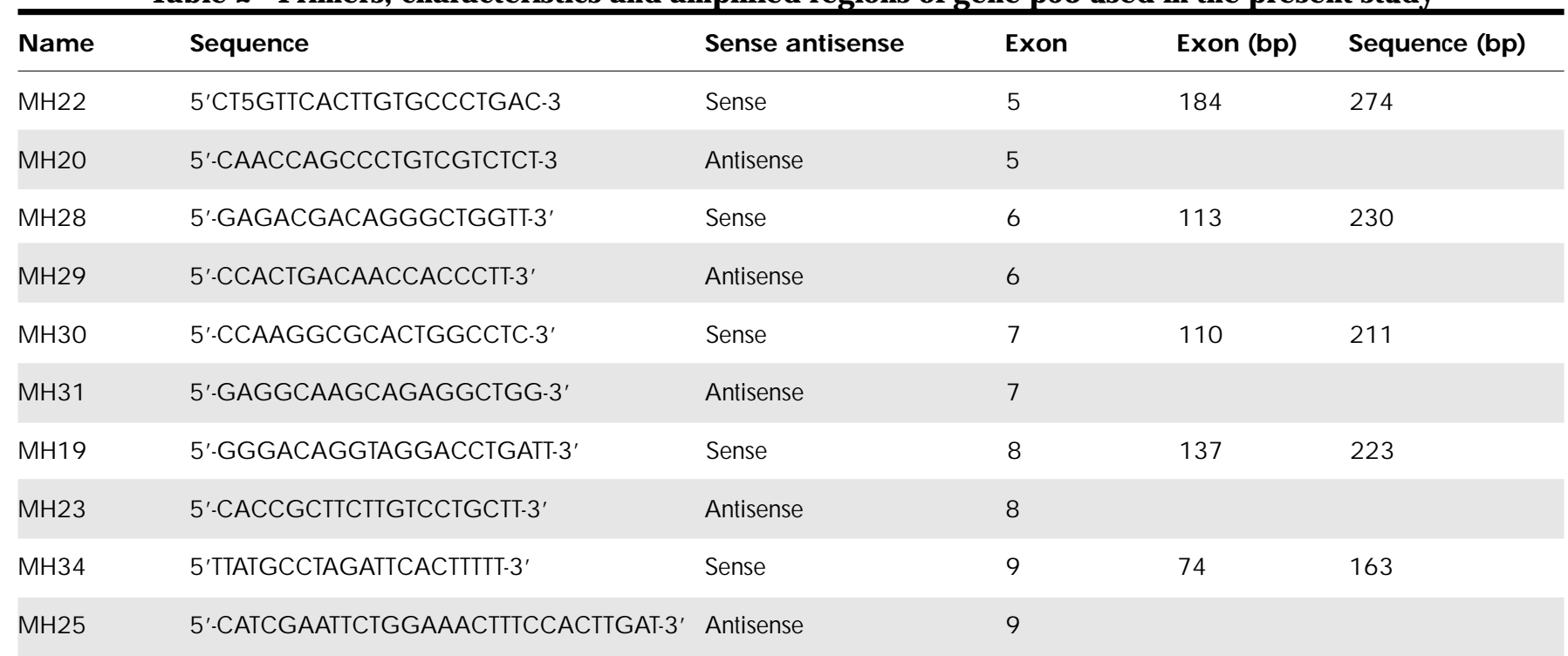


Kusafuka et al. ${ }^{6}$ studied 13 cases of Wilms' tumor and detected no mutation of the p53 gene. In a study of 38 cases of Wilms' tumor, Waber et al. ${ }^{16}$ also did not detect any mutation of the $\mathrm{p} 53$ gene. Malkin et al. ${ }^{9}$ detected 2 cases with mutations out of a total of 21 . One of the patients had an advanced stage tumor with favorable histology and the other had focal anaplasia. Bardeesy et al. ${ }^{10}$ did not observe mutations of the p53 gene in 92 cases of Wilms' tumor with favorable histology.

Based on these findings, the absence of detection of mutations observed in the present study agrees with current data, despite the small number of cases analyzed. We suggest that the number of Wilms' tumor specimens to be evaluated should be increased in future studies, especially those from patients with unfavorable histology and advanced stage disease, and that more comprehensive studies should be performed byanalyzing the remaining coding exons of the p53 gene and their expression, in order to better determine any possible association between alterations of p53 gene and Wilms' tumor.

\section{REFERENCES}

1. Fields $\mathrm{S}$, Jang $\mathrm{S}$. Presence of a potent transcription activating sequence in the p53 protein. Science 1990;249:1046-9.

2. Levine A, Momand J, Finlay C. The p53 tumor suppressor gene. Nature (Lond) 1991;351:453-6.

3. Vogelstein B, Kinzler K. p53 function and dysfunction. Cell 1992;70:523-6.

4. Chang F, Syrjanen S, Syrjanen K. Implications of the p53 tumor-suppressor gene in clinical oncology. J Clin Oncol 1995;13:1009-22.

5. Levine AJ. The p53 tumor suppressor gene. N Engl J Med 1992;326:1350-2.

6. Kusafuka T, Fuzukawa M, Oue T, Komoto Y, Yoneda A, Okada A. Mutation analysis of the $p 53$ gene in childhood malignant solid tumors. J Pediat Surg 1997; $32: 1175-80$.

7. Breslow N, Beckwith JB, Ciol M, Sharples K. Age distribution of Wilms'tumor: report from the National Wilms' Tumor Study. Cancer Res 1988;48:1653-7.

8. Clericuzio C. Clinical phenotypes and Wilms' tumor. Med Pediat Oncol 1993;21:182-7.

9. Malkin D, Sexsmith E, Yeger H, Williams BRG, Coppes MJ. Mutations of the p53 tumor suppressor gene occur infrequently in Wilms' tumor. Cancer
Res 1994:54:2077-9.

10. Bardeesy N, Falkoff D, Petruzzi M, et al. Anaplastic Wilms' tumor: a subtype displaying poor prognosis harbors p53 gene mutations. Nature Genet 1994;7:91-7.

11. D'Anglio GJ, Evans A, Breslow N, et al. Treatment of Wilms' tumor: results of the third National Wilms' Tumor Study. Cancer (Phila) 1989;64:349-60.

12. SambrookJ, Fritsch EF, Maniats T. Molecular Cloning: a laboratory manual. $2^{\text {nd }}$ ed. Cold Spring Harbor, NY: Cold Spring Harbor; 1989.

13. Hsiao M, Yu AA, Yeargin J, Ku D, Haas M. Nonhereditary p53 mutations in t-cell acutelymphoblastic leukemia are associated with relapse phase. Blood 1994;83:2922-30.

14. Hayashi K. PCR-SSCP. A simple and sensitive method for detection of mutations in the genomic DNA. PCR Meth Applications 1991;1:34-8.

15. Greenblatt M, Bennett WP, Hollstein M, Harris CC. Mutations in the p53 tumor suppressor gene: clues to cancer etiology and molecular pathogenesis. Cancer Res 1994;54:4855-78.

16. Waber PG, Chen J, Nisen PD. Infrequency of ras, p53, WT 11 or RB gene alterations in Wilms' tumor. Cancer 1993;72:3732-8. resumo

CONTEXTO: M utações do gene supressor tumoral p53 são observadas como as ma is freqüentes alterações em neoplasias humanas em adultos. Em oncologia pediátrica, entretanto, são pouco identificadas. 0 tumor de W ilms é uma neoplasia renal comum em crianças e associa-se com mutações do gene W T1. A correlação entre tumor de W ilms e alteraç̧ões do gene p53 não está bem estabelecida, sendo baixa a freqüência tumoral, podendo haver associação com doença em estágio avançado e histologia desfavorável.

TIPO DE ESTUDO: Relato de caso.

RELATO DE CASO: Foi realizar uma triagem para mutações do gene p53 pelo método de PCR-SSCP e seqüenciamento de DN A nos casos sugestivos de mutação em tumor de W ilms. Avaliação do gene p53 nos exons 5-9 em amostras de DN A extraídos de 10 tumores de W ilms de crianças em diferentes estágios pelo método de PCR-SSCP e seqüenciamento de DNA. Alterações na análise do SSCP foram observadas em duas amostras no exon 8. As prováveis mutações não foram confirmadas pelo seqüenciamento de DNA. A ausência de mutações de ponto do gene p53 observada nas 10 amostras de tumor de W ilms estudadas está de acordo com a literatura, sendo o seqüenciamento de DN A fundamental para a confirmação de possíveis mutações.

Palavras-chave: Tumor de W ilms. Gene p53. PCR-SSCP. Tumores sólidos.

\section{publishing information}

Ricardo Defavery, MD. Department of Pediatrics, Faculty of Medicine of Ribeirão Preto, University of São Paulo, Ribeirão Preto, Brazil.

José Alexandre Rodrigues Lemos, PhD. Laboratory of molecular Biology, Department of Pediatrics, Faculty of Medicine of Ribeirão Preto, University of São Paulo, University of São Paulo, Ribeirão Preto, Brazil.

Simone Kashima, PhD. Laboratory of molecular Biology, Fundação Hemocentro de Ribeirão Preto, University of São Paulo, Ribeirão Preto, Brazil. José Eduardo Bernardes, MD. Department of Pediatrics, Faculty of Medicine of Ribeirão Preto, University of São Paulo, University of São Paulo, Ribeirão Preto, Brazil.

Carlos Alberto Scridelli, MD. Assistant Physician, Department of Pediatrics, Faculty of Medicine of Ribeirão Preto, University of São Paulo, University of São Paulo, Ribeirão Preto, Brazil.

Dimas Tadeu Covas, MD. Director of Fundação Hemocentro de Ribeirão Preto, University of São Paulo, Ribeirão Preto, Brazil.

Luiz Gonzaga Tone, MD. Department of Pediatrics, Faculty of Medicine of Ribeirão Preto, University of São Paulo, University of São Paulo, Ribeirão Preto, Brazil.

Sources of funding: Not declared Conflict of interest: Not declared

Last received: 17 de August 1999

Accepted: 21 September 1999

Address for correspondence:

Luiz Gonzaga Tone

Departamento de Pediatria da Faculdade de Medicina de

Ribeirão Preto da Universidade de São Paulo

Av. Bandeirantes, 3900

Ribeirão Preto/SP - Brasil - CEP 14049-900

E-mail: Igtone@fmrp.usp.br 